\title{
From Microbial Ecology to Innovative Applications in Food Quality Improvements: the Case of Sourdough as a Model Matrix
}

\author{
Mattia Pia Arena ${ }^{1, *}$, Pasquale Russo ${ }^{1}$, Giuseppe Spano ${ }^{1}$ and Vittorio Capozzi ${ }^{2, * \mathbb{D}}$ \\ 1 Department of the Sciences of Agriculture, Food and Environment, University of Foggia, Via Napoli 25, \\ 71122 Foggia, Italy; pasquale.russo@unifg.it (P.R.); giuseppe.spano@unifg.it (G.S.) \\ 2 Institute of Sciences of Food Production, National Research Council (CNR), c/o CS-DAT, \\ Via Michele Protano, 71121 Foggia, Italy \\ * Correspondence: mattiapia.arena@unifg.it (M.P.A.); vittorio.capozzi@ispa.cnr.it (V.C.); \\ Tel.: +39-(0)881-589-303 (M.P.A.); +39-(0)881-630-201 (V.C.)
}

Received: 31 December 2019; Accepted: 28 January 2020; Published: 30 January 2020

\begin{abstract}
Since millennia, humankind has exploited microbial diversity associated to give food matrices in order to obtain fermented foods and beverages, resulting in products with improved quality and extended shelf life. This topic has received deserved and continuous interest in the scientific community, for the reason of its significance as a driver of innovation in the food and beverage sector. In this review paper, using sourdough as a model matrix, we provide some insights into the field, testifying the relevance as a transdisciplinary subject. Firstly, we encompassed the prokaryotic and eukaryotic microbial diversity associated with the sourdough ecosystems. The importance of this micro-biodiversity in the light of flour-related chemical diversity was examined. Finally, we highlighted the increasing interest in microbial-based applications oriented toward biocontrol solution in the field of sourdough-based products (i.e., bread).
\end{abstract}

Keywords: sourdough; bread; bacteria; yeast; lactic acid bacteria; quality; safety; biodiversity; innovation; food

\section{Microbial Ecology of Sourdough}

When and how sourdough was used for the first time to make bread has been lost in the mists of the time. Actually, it is well-known that the ancient Egyptians already had the habit of using sourdough to produce bread [1]. During the early European Middle ages, keeping the barm, i.e., the foam forming on the liquid surface following the fermentation of wine and beer, was the way to ascertain a fresh inoculum of microorganisms for baking. However, over the years, the idea to preserve purpose-culture microorganisms, for example, through the storage of the small aliquots of bread dough to be refreshed and utilized for the production of subsequent bread making [1], has been remarkably fruitful and helped to select distinctive microbial communities [2]. In Mediterranean and Middle Eastern areas, the tradition of making sourdough bread is passed down generations to generations and even in the United States of America, in particular in San Francisco bay, a particular microorganism strain, i.e., Lactobacillus sanfranciscensis, was discovered and widely studied since 1849 [3,4].

The production and marketing of bread microbial starters, to use as dough acidifier, was dated to the beginning of XX century, in the 1920s, and the sold product consisted of a pre-gelatinized flour and lactic acid. Afterward, dried sourdoughs have taken hold as ordinary bakery ingredients [5].

Sourdough, derived from the Old English "sour" and "dough" and having the meaning of "something kneaded and fermented", was traditionally achieved by the combination of wheat flour, which was inherently a microbial inoculum of autochthonous homo- and hetero-fermentative lactic 
acid bacteria (LAB), water, salt and yeast, the latter mainly recovered by the fermentation of alcoholic beverages [6]. If on one hand, yeasts are able to convert wheat (or other types of) flour into something more edible and appetizing by fermentation. On the other hand, LAB have an impact to texture, palatability, nutritional values and staling of this irresistible dish called bread, contributing to donate mouthwatering characteristics of this product $[7,8]$. As a matter of fact, LAB are able to enrich the dough of several metabolites including organic acids, exopolysaccharides, antimicrobial compounds, and enzymes. Exopolysaccharides have been shown to enhance the viscoelastic properties of dough conferring allowing increased loaf volume, lower crumb hardiness and longer shelf life [8]. The ratio of LAB yeasts in sourdough is commonly 100:1, although, sometimes, it can be lower [9]. Among organic acids, LAB are able to produce lactic acid that confers aroma and acidifies the food matrix acting as anti-spoilage agent [10]. Moreover, as LAB present in sourdough show mainly hetero-fermentative metabolism, also acetic acid can be produced during dough fermentation and can contribute to acidify the dough [11].

The species of yeast characterized in sourdough include Saccharomyces cerevisiae (also named Saccharomyces fructuum) as the principal [12]. Next to this specie, it lists other as well Saccharomyces exiguous (also named Torulopsis holmii, Candida holmii, Saccharomyces minor), Candida humilis (also named Candida milleri), Issatchenkia orientalis (also named Candida krusei), Pichia anomala (also called Hansenula anomala), Saturnispora saitoi (also called Pichiasaitoi), Torulaspora delbrueckii (also named Torulopsis colliculosa, Candida colliculosa, Saccharomyces delbrueckii, Saccharomyces inconspicuous), Debaryomyce shansenii (also named Torulopsis candida, Candida famata), and Pichia membranifaciens, Candida lambica, Candida valida, and Candida glabrata $[6,13,14]$. Nevertheless, the variability of yeast species is highly correlated to dough hydration, type of cereal source, temperature of fermentation, and sourdough maintenance temperature $[9,15]$.

Moreover, sourdough-associated bacteria population are also highly variegated and depend on source and type of dough [16] (Figure 1).

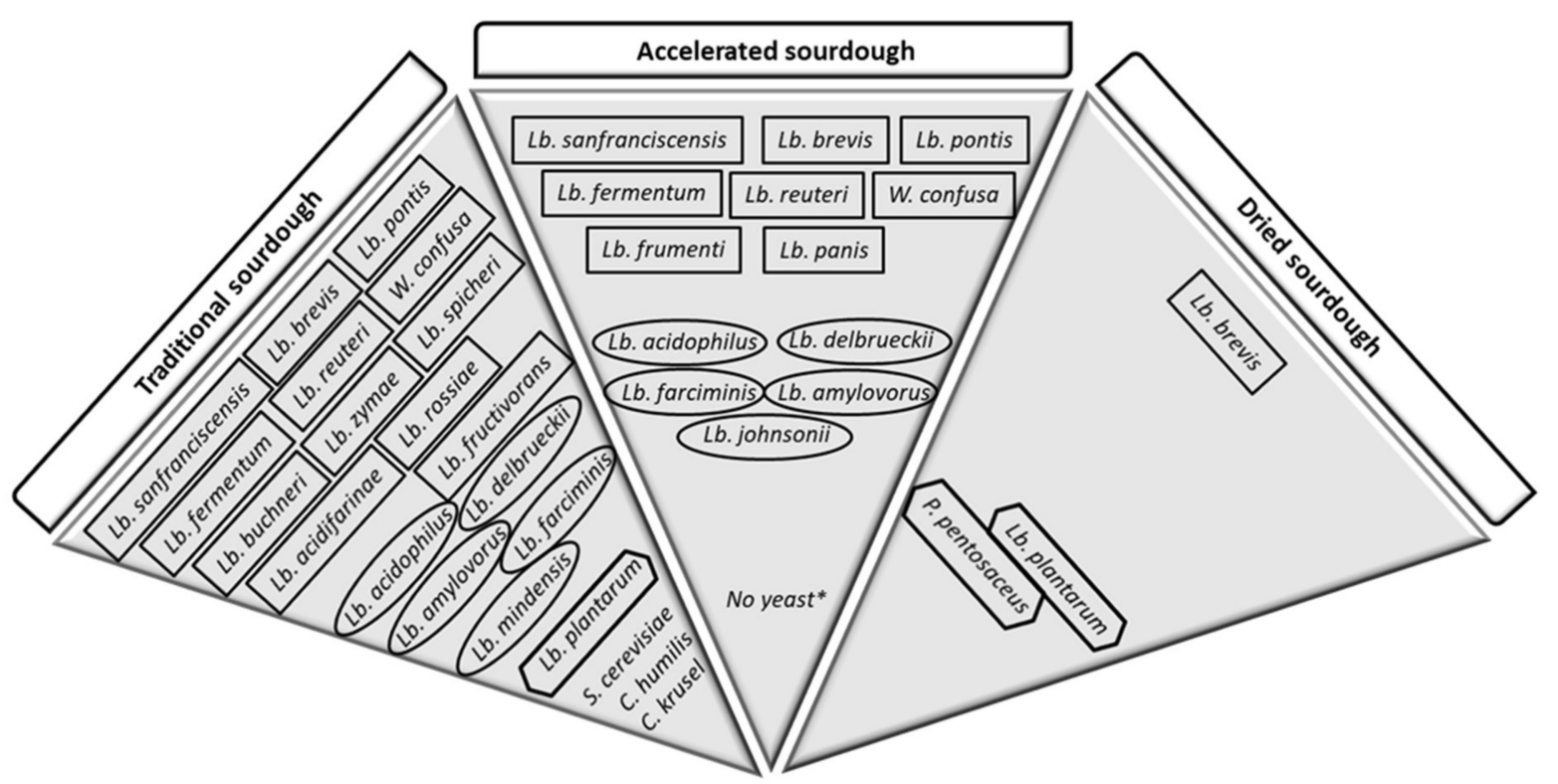

Figure 1. Principal microflora of three main types of sourdough (traditional, accelerated, and dried). Quadrangular shape = obligate hetero-fermentative strains; oval shape $=$ obligate homo-fermentative strains; hexagonal shape $=$ facultative hetero-fermentative strains; Lb. = Lactobacillus; P. = Pediococcus; W. $=$ Weissella $;$ S. = Saccharomyces; $C .=$ Candida ${ }^{*}$ S. cerevisiae may be added.

The state of the art concerning the knowledge of bacteria isolated from traditional sourdough, i.e., sourdough obtained by continuous refreshment in order to keep a high metabolic activity of microorganisms, includes species of Lactococcus, Leuconostoc, Enterococcus, Pediococcus, Streptococcus, 
and Weissella, although Lactobacillus strains are the most frequently isolated [17]. Among Lactobacillus genus, $L b$. sanfranciscensis, $L b$. plantarum and $L b$. brevis are the manly species found, probably because the favorable growth conditions of these species coincide with the technical parameters of traditional sourdough production that are $20-30{ }^{\circ} \mathrm{C}$ and $\mathrm{pH}$ of 3.8-4.5. Besides the aforementioned species, Lactobacillus mindensis, Lb. spicheri, Lb. rossiae, Lb. zymae, Lb. acidifarinae, Lb. hammesii, and Lb. nantensis are also frequently found [10,18-20]. Afterward, as the case of other microbial starter used in the food industry, e.g., daily, oenological and vegetal manufactory, also for bakery production, in more recent years, allochthonous microbes have been selected and characterized in order to standardly and quickly carry out the fermentation process. It is the case of the so-called accelerated sourdough process, which does not include a daily refreshment and is fairly chosen by industry, with a typical microflora characterized by a mixture of obligate hetero-fermentative bacteria, such as $L b$. pontis, Lb. panis, $L b$. sanfranciscensis, Lb. brevis, Lb. fermentum, $L b$. reuteri, Weissela confuse and $L b$. frumenti, and obligate homo-fermentative strains, such as $\mathrm{Lb}$. acidophilus, Lb. delbrueckii, Lb. farciminis, Lb. amylovorus (rye), Lb. johnsonii [21]. In the case of this type of sourdough, the high temperature of fermentation, between $30{ }^{\circ} \mathrm{C}$ and $50^{\circ} \mathrm{C}$, the lower $\mathrm{pH}$ value, usually less than 3.5 , and the starvation condition due to low frequency of refreshment lead to a very low metabolic activity [22]. Moreover, one further method of sourdough production is the dry process that makes storage processes easier for industries and comprises LAB strains able to resist to drying such as hetero-fermentative $L b$. brevis, facultative hetero-fermentative Pediococcus pentosaceus and $\mathrm{Lb}$. plantarum strains. These types of sourdough are made by traditional sourdough fermentation with succeeding water evaporation [23].

Well-known is the mutually beneficial relationship between the two cultures exploited in the yogurt production, i.e., Streptococcus thermophilus and Lactobacillus delbrueckii subsp. Bulgaricus; in fact, the inoculum of the aforementioned strains results in a higher and faster lactic acid production and development of flavor than those that can be obtained from individual cultures [24]. In more detail, the high proteolytic ability of Lactobacillus delbrueckii subsp. bulgaricus in milk leads to the efficient breakdown of proteins, which considerably enhances the growth of $S$. thermophilus. At the same time, S. thermophilus produces formic acid which stimulates Lactobacillus delbrueckii subsp. bulgaricus growth. In sourdough, a type of protocooperation has been noted studying wild sourdoughs showing associative growth of the bacterial strain Lactobacillus sanfranciscensis and the yeast strain Candida milleri [25]. In detail, $L b$. sanfranciscensis ferments sugars in bread dough producing lactic and acetic acids, ethanol and carbon dioxide dropping the $\mathrm{pH}$ up to 3.5. Such acidic condition hinders most of the bakery yeasts, including Saccharomyces cerevisiae, except $C$. milleri (and related species), which benefits of the lack of capacity of the other yeasts to metabolize nutrients. In turn, $C$. milleri provides free amino acids and other nutrients for $L b$. sanfranciscensis. Neither organism competes against each other for substrates; indeed, C. milleri is not able to utilize maltose, which is one of the main dough carbohydrates, while $L b$. sanfranciscensis prefers maltose as carbon source. Interestingly, Lb. sanfranciscensis catabolizes maltose producing glucose-1-phosfate, which is further fermented by heterofermentative pathway, and free glucose, which is excreted in dough and utilized by C. milleri [26]. The duo Candida milleri and $L b$. sanfranciscensis, mostly counted in a yeast:bacteria ratio of about 1:100, has been found in sourdoughs from around the world highlighting their astonishing and ingrained adaptation to the dough environment [9].

The cooperation between yeast and lactic acid bacteria in sourdough is further supported by the example of $S$. cerevisiae which can be able to secrete valine and leucine. These amino acids are in turn used by LAB, e.g., Lb. plantarum species $[15,27]$. Altruistically, LAB can hydrolyze maltose, which S. cerevisiae benefits from [28].

Furthermore, evidence of mutualistic relations was underlined by the production of non-proteinaceous components by $S$. cerevisiae that stimulates $L b$. sanfranciscensis, while this lactic acid bacterium produces lactic acid which is utilizable by yeast to grow $[29,30]$.

Thus, although everyone is used to thinking about food fermentation as a process carried out by single microbes, the association for microbes constitutes a strong asset that should be well highlighted [31,32]. 
The quality of fermented end-product benefits from the presence of bacteria consortia due to an enlargement of organoleptic features, including texture, taste, flavor, viscosity. Moreover, mutually beneficial interactions within a co-existing microbial community can prevent the entrance of other microbial species, including spoilage microbes with a consequently longer shelf life [33-39].

\section{Sourdough Impact on the Flour Mixture: When Microbial Diversity Meets Chemical Diversity}

The cooperation of yeasts and LAB convert flour mixture into something more edible and mouthwatering by fermentation. Depending on the type of flour used, the additional ingredients (water, salts and, eventually, other components such as olive oil, fat, sugar, milk, butter, olives, tomatoes, etc.,) and the technological conditions of production, yeasts and LAB impact on overall quality of the end product, including texture, palatability, nutritional values and staling $[7,8]$.

Certainly, wheat and rye flours are the most popular cereal used for bread-making [21]. Rye flour contains a higher amount of pentosans, pentose-containing polysaccharides consisting of xylose and arabinose with high water-binding capacity, than wheat flour, and this limits the crumb forming of bread due to a minor formation of the gluten network. However, the addition of sourdough cultures normally drops the $\mathrm{pH}$ values and leads pentosans to be more hydro-soluble and to swell causing a gluten-like structure. The acidic conditions also reduce the $\alpha$-amylase activity which determines a less sticky crumb, higher loaf volume, less elastic and extensible structure [40].

However, in more recent years, gluten-free bread has gathered an ever-bigger slice of the bakery market, albeit the less presence of protein network in these products makes it difficult to reach a final quality comparable to that of traditional bread. Thus, novel flours, such as barley, oat, jackfruit, brown rice, corn starch, sorghum, millet, buckwheat, and soy flours are used as an alternative source for preparations for celiac consumers [41]. Additionally, the growing attention of consumers for healthy foods drives the bakery industry to use flours with a contribution of compounds containing functional activities in order to obtain functional bread. For example, loaves of bread made of whole-grain barley flour have been shown to reduce blood cholesterol and glycemic index and to enhance satiety [7]. Moreover, chickpea, lentil, and bean flours are used mixed to wheat flour in order to improve nutritional, texture and aromatic properties [16], while mixture of chickpea, amaranth, quinoa and buckwheat flours (ratio 5:1:3:1) and selected lactobacilli strains, i.e., Lactobacillus plantarum and Lactococcus lactis subsp. lactis, highlighted a higher $\gamma$-aminobutyric acid (GABA) content [42].

However, depending on the type of flour used, the bread-making process may cause chemical, biochemical, and physical transformations of added ingredients [40]. In fact, the flour composition is a key aspect to consider for dough fermentation as variations of carbohydrate, protein, lipid, micronutrient contents influence the structure and the overall quality of end-product. For example, the absence of the gluten protein complex in most non-wheat flours determines a low elasticity and a weak structure of the dough.

Certainly, the utilization of carbohydrates by LAB and yeasts as carbon source is the most important metabolic process during sourdough fermentation. Carbohydrates are the main fraction of flour (around $75 \%$ of the weight) and starch is the highest component (around $99 \%$ of carbohydrate content), albeit simple sugars, cellulose, and fiber can be also found. Starch, whose chemical structure is made by two glucose polymer named amylose and amylopectin, is preserved in the kernel in form of spherical granules that are broken during milling and become available for hydrolytic enzymes (content in the flour) and water hydration. Thus, the complex network of glucose polymers is hydrolyzed to simpler molecules, such as maltose and glucose. Starting from glucose, Lactobacilli are able to produce lactic acid (in the case of the homo-fermentative LAB) or lactic acid and other compounds (hetero-fermentative $\mathrm{LAB}$ ), such as $\mathrm{CO}_{2}$, acetic acids and/or ethanol, depending on the availability of substrates acting as the electron acceptor. The ration of lactic acid and acetic acid has a clue on the aromatic quality of the end product. In wheat flour, the most available carbon source is maltose followed by sucrose, glucose, and fructose, along with some trisaccharides such as maltotriose and raffinose [43]. The glucose amount increases during fermentation, whereas sucrose decreases in the presence of yeasts due to 
the action of invertase [44]. Homofermentative LAB mainly ferment glucose, and other hexoses after isomerization and/or phosphorylation [45], producing lactic acid through glycolysis (homolactic fermentation), while heterofermentative $\mathrm{LAB}$ produce lactic acid, $\mathrm{CO}_{2}$, acetic acid, and/or ethanol through the 6-phosphogluconate/phosphoketolase (6-PG/PK) pathway (heterolactic fermentation).

Pentoses are phosphorylated and can be metabolized through the 6-PG/PK pathway (thus, only heterofermentative $\mathrm{LAB}$ can ferment pentoses), prior to the action of epimerase or isomerase, resulting in the production of equimolar amounts of lactic and acetic acid (without $\mathrm{CO}_{2}$ formation). Disaccharides are also catabolized by LAB due to hydrolases and/or phosphohydrolases in order to have accessible monosaccharides to be fermented. Thus, sourdough LAB release glucose into medium and this sugar contributes to the yeast develop which is the major responsible for dough leavening. Depending on the yeast, the form in which it is added in the dough and the fermentable sugar availability, the time for the beginning of fermentation varies [46]. The species S. cerevisiae is a facultative anaerobic yeast and can metabolize glucose both via aerobic and via anaerobic pathways producing, in the first case carbon dioxide (via tricarboxylic acid cycle) and, in the second case carbon dioxide and ethanol (via Embden-Meyerhoff-Parnas glycolytic pathway). Normally, at the beginning of fermentation, the presence of oxygen in the dough, due to the mixing of flour and water, determines the aerobic catabolism of sugars and, as the environment becomes anoxic due to the accumulation of carbon dioxide that is produced, anaerobic fermentation follows [44,47].

Sourdough bacteria can produce exopolysaccharides (EPS) from sucrose through the activity of glycosyltransferases, as in the case of some strains of Lb. sanfranciscensis whose EPS, produced during wheat and rye fermentation, are composed of fructose. The EPS contribute to improving the rheological properties of dough and, consequently, the volume, texture, and keepability of end products [48].

Moreover, proteolysis, i.e., the breakdown of proteins into peptides and amino acids, is one of the most important processes that affects the quality of end-products [49]. In wheat flour, protein content is ranged between $8 \%$ and $16 \%$. Depending on protein content, the use of the flour is defined and it can be to obtain bread (commonly weather the protein content is about 10-16\%), pasta (weather the protein content is about $12-14 \%$ ) or cake, cookies and pastries (weather the protein content is around $8-10 \%$ ). In effect, the main percentage of proteins is the fraction of gliadin and glutenin (around $85 \%$ of the total protein content) which takes a crucial role in the formation of network of the end product as gluten (the hydrated form of the mixture of gliadin and glutenin) provides to retain carbon dioxide made during fermentation and determines the dough expansion. Other proteins are globulins, albumins, and enzymes such as amylase.

In an acidic condition, such as those of bread fermentation, endogenous flour proteinases, are responsible for the degradation of proteins into peptides. For example, endogenous proteinases of rye are activated by acidic condition of sourdough and hydrolyze proteins into peptides and amino acids [50]. Afterwards, bacterial intracellular and extracellular peptidases are liable for degradation of peptides into amino acids, while yeast proteinase do not intervene in the hydrolysis process [51,52]. The type of available peptides and the catabolic ability of LAB define the amino acid and amino acid derivatives, coming from amino acid deamination, transamination or decarboxylation, produced during fermentation; both amino acid and amino acid derivatives contribute to the aroma quality [49]. For example, glutamate, which confers palatable feature, and 2-acetyl pyrroline, which confers roasted odor, are gained respectively by conversion of glutamine and arginine though deiminase pathways [53]. Sourdough fermentation can enhance the free amino acid concentration in wheat and rye doughs [28], probably due to proteinase and peptidase activities by lactic acid bacteria [54]. For instance, the proteolytic system of a strain of $L b$. sanfranciscensis has been shown to include proteinase, dipeptidase, and aminopeptidase [55]. Some lactobacilli strains, isolated from sourdough, were shown to be able to hydrolyse albumin, globulin, and gliadin fractions during wheat sourdough fermentation [56] and Pro-rich peptides, including the most potent inducer of gut-derived human T-cell lines in celiac sprue. Sourdough bread made from wheat and long fermented by these selected lactobacilli contributes to decrease the level of gluten intolerance in humans [51]. 
The enzyme phytase is typically present in wheat flour and can be also provided by bread yeast. This enzyme degrades phytic acid which is an antinutritional compound found in whole grains due to its capability to reduce the bioavailability of important cations such as zinc, iron, calcium. Several sourdough lactic acid bacteria, such as Lb. sanfranciscensis and Lb. plantarum, can be able to produce phytase leading to a considerable reduction of phytic acid in the end product $[57,58]$.

Lipids, also present in raw material or added in the form of fats or oils in order to improve dough handling and crumb appearance, can be oxidized and converted into aldehydes which are also involved in the formation of aroma profile [59-61].

Overall, the sourdough microflora, including LAB and yeasts, together with enzymes present in flour and influenced by the type of flour and baking conditions, determine the global quality of end products - even in terms of aroma characteristics, which include a mixture of odorous and tasty compounds such as alcohols, esters and carbonyls [59,62-64]. The volatile compounds are produced during sourdough fermentation in a multiple-step process of about 12-24 $\mathrm{h} \mathrm{[44].}$

In recent years, the growing demand by the consumers for healthy aspect of foods, which at the same time maintain high tasty and palatable quality, pressed to investigate bioactive compounds available in bakery products [7]. LAB, apart from organic acids, can produce a number of metabolites such as exopolysaccharides (EPS) (i.e., levan, levansucrase, fructan, dextran, reuteran), anti-microbial substances (i.e., bacteriocins) and a variety of species-specific enzymes (i.e., $\alpha$-amylase, pectinase, phytase, etc.,) that have been shown to impart beneficial effects on functional, nutritive, texture values, and staling of bread. Numerous studies focused on EPS produced by LAB and showed double functionality, i.e., prebiotic ability on sourdough microflora associated to the technological enhancement of end product, such as including water absorption of the dough, dough machinability, better rheology properties, increased loaf volume and retarded bread staling [8,65-67].

The utilization of sourdough for bread making has been correlated to the increase of vitamins and nutrients, such as folate $[68,69]$. Thiamine and folates have been reported higher after a long fermentation time $[64,65,70]$. Interestingly, sourdough fermentation creates optimal acidic conditions that promote the degradation of phytic acid by activation of phytases [50].

Overall, sourdough utilization ameliorates quality and increases the shelf-life of bread [21] due to the presence of lactic acid bacteria and yeast consortia that produce a great number of metabolites showing positive effects on palatability [59]. LAB are responsible for a major acidity that positively influences the shelf life and reduces the growth of spoilage fungi and bacteria [71]. Additionally, sourdough fermentation, which is a longer process than the industrial fermentation method with microbial starters, results in an increased mineral bioavailability and reduced phytate content, and a more regular alveolation due to production of the slower and gradual carbon dioxide [22,72,73].

\section{Sourdough and Biopreservation}

Bread, such as other baking products, undergoes chemical and microbiological deteriorations, thus shelf life can be two or three days. For example, staling, an undesirable increase in crumb firmness associated with an increase in crust softness, is related to chemical changes in starch structure and moisture migration. Moreover, several fungi can alter end-products palatability due to their mycelia. For example, Aspergillus niger can create black sporulating bodies on bread surface, Aspergillus glaucus and Aspergillus flavus produce green blanket-like, Penicillium spp. and Neurospora sitophila can cover, respectively, bread with blue and pink sporophore, whereas, Rhizopus nigricans and Mucor sp. can visibly appear on loaf surface showing grey defects. In addition, some strains of Bacillus subtilis, Bacillus mesentericus, and Bacillus licheniformis can produce extracellular polysaccharides that give undesirable ropy texture [74].

Besides this, one of the goals of the bakery industry is to extend shelf life focusing on reducing staling and counteracting the microbiological spoilage adopting physic, chemical, and microbiological strategies. Calcium and sodium propionate, sorbate and acetate salts are often used in commercially produced products due to their effective anti-mycotic, anti-bacteria and anti-yeast action. Alternatively, 
loaves can be treated with ultraviolet, infrared, or microwave radiation to inactivate mold or modified atmosphere can be used to package. However, the most bio-alternative to naturally reduce bread deterioration is to rely on acidic capability of sourdough. In fact, the organic acids, such as lactic, acetic, caproic and phenyllactic acids, produced by LAB in dough create unfavorable environment for fungi growth [75]. For example, it has been shown that Lb. sanfranciscensis displays a broad antifungal activity due to the synergic action of a mixture of acetic, caproic, formic, propionic, butyric and n-valeric acids, acting against Fusarium, Penicillium, Aspergillus and Monilia fungi [23]. Culture filtrate of Lb. plantarum strain isolated from sourdough was selected for its antifungal activity inhibiting conidial germination of Eurotium repens, Eurotium rubrum, Penicillium corylophilum, Penicillium roqueforti, Penicillium expansum, Endomyces fibuliger, Aspergillus niger, Aspergillus flavus, Monilia sitophila, and Fusarium graminearum [76]. The fungicidal activity was attributed to phenyllactic acid and the minimum active concentration of this compound was found at a concentration of $50 \mathrm{mg} \cdot \mathrm{ml}^{-1}$.

Moreover, antimicrobial molecules, such as bacteriocins and bacteriocin-like, can be produced by sourdough LAB. For example, the bacteriocin bavaricin, firstly found to be produced by strain of Lb. sakei (formerly named $L b$. bavaricus) isolated from sourdoughs [77], and bacteriocin plantaricin, produced by L. plantarum isolated from sourdough [71], have been shown to have antimicrobial activity. Furthermore, the antibiotic reutericyclin, for the first time isolated by a strain of Lb. reuteri yielded from rye-based sourdough [78], is largely active against spoilage organisms.

Caproic acid associated with acetic, formic, propionic, butyric and n-valeric acids produced by a strain of $L b$. sanfranciscensis CB1 were revealed to be the bacterial mixture inhibiting Fusarium, Penicillium, Aspergillus, and Monilia growth in bread [55]. The synergistic combination of Lb. plantarum strain and calcium propionate has been shown to lead to an increase of antifungal activity in wheat bread [79].

Two strains of Lactobacillus rossiae and Lactobacillus paralimentarius from sourdoughs for bread and panettone production were characterized for their antifungal properties against three indicator cultures, i.e., Aspergillus japonicus, Eurotium repens, and Penicillium roseopurpureum [80]. Strains of LAB isolated from rye sourdoughs, i.e., Lactobacillus sakei, Pediococcus acidilactici, Pediococcus pentosaceus, resulted active to inhibit ropes-producing Bacillus subtilis and Aspergillus, Fusarium, Mucor and Penicillium fungi through the production of bacteriocin-like inhibitory substances designated as sakacin and pediocin [81].

\section{Conclusions}

Sourdough is the result of a complex microbial consortium in which the different prokaryotic and eukaryotic species interact with each other by creating the best conditions to coexist and exploit the environment in which they live. The achievement of these interactions produces, from the human point of view, a unique fermented product whose origin is lost over time. The present study aimed to give an overview of microbial communities currently analyzed in different matrices and, then, to link the presence of these microorganisms to the chemical characteristics of the end-products in relation to the intrinsic factors of the flour matrix and the extrinsic factors of the process conditions. As a matter of fact, the understanding of the double relationship between chemical diversity and microbial diversity associated with a given fermented matrix could offer continuous opportunities to cope with emerging instances of the consumers. Sourdough represents an ideal model matrix in reason of the co-existence of prokaryotic and eukaryotic microorganisms and of the complex chemistry of the different flours. In terms of relevance in the innovation landscape, we particularly focus on the aspects related to bioprotection, which allow finding sustainable solutions to the needs of the market. Starting from the study of microbial ecology in sourdoughs and ways of their interaction in the different fermentation conditions, new innovative applications could be provided in term of food quality improvements as greater safety, better organoleptic and nutritional characteristics.

Author Contributions: Investigation, M.P.A., P.R., G.S., and V.C.; conceptualization, M.P.A., P.R., G.S., and V.C.; literature search, M.P.A., P.R., G.S., and V.C.; writing-original draft preparation, M.P.A. and V.C.; writing-review and editing, P.R. and G.S. All authors have read and agreed to the published version of the manuscript. 
Funding: Pasquale Russo is the beneficiary of a grant by MIUR in the framework of 'AIM: Attraction and International Mobility' (PON R\&I 2014-2020) (practice code D74I18000190001).

Acknowledgments: We would like to thank the two anonymous reviewers for their suggestions and comments.

Conflicts of Interest: The authors declare no conflict of interest.

\section{References}

1. Capozzi, V.; Fragasso, M.; Romaniello, R.; Berbegal, C.; Russo, P.; Spano, G. Spontaneous food fermentations and potential risks for human health. Fermentation 2017, 3, 49. [CrossRef]

2. Pollock, C.J.; Cairns, A.J. Fructan metabolism in grasses and cereals. Annu. Rev. Plant Physiol. Plant Mol. Biol. 1991, 42, 77-101. [CrossRef]

3. De Vuyst, L.; Neysens, P. The sourdough microflora: biodiversity and metabolic interactions. Trends Food Sci. Technol. 2005, 16, 43-56. [CrossRef]

4. Jay, J.M.; Loessner, M.J.; Golden, D.A. Modern Food Microbiology, 7th ed.; Food Science Text Series; Springer: New York, NY, USA, 2005; ISBN 978-0-387-23180-8.

5. Brandt, M.J. Sourdough products for convenient use in baking. Food Microbiol. 2007, 24, 161-164. [CrossRef] [PubMed]

6. Behera, S.S.; Ray, R.C.; Ray, R.C. Sourdough Bread. Available online: https://www.taylorfrancis.com/ (accessed on 26 September 2019).

7. Mariotti, M.; Garofalo, C.; Aquilanti, L.; Osimani, A.; Fongaro, L.; Tavoletti, S.; Hager, A.-S.; Clementi, F. Barley flour exploitation in sourdough bread-making: A technological, nutritional and sensory evaluation. LWT - Food Sci. Technol. 2014, 59, 973-980. [CrossRef]

8. Torrieri, E.; Pepe, O.; Ventorino, V.; Masi, P.; Cavella, S. Effect of sourdough at different concentrations on quality and shelf life of bread. LWT - Food Sci. Technol. 2014, 56, 508-516. [CrossRef]

9. Gobbetti, M. The sourdough microflora: Interactions of lactic acid bacteria and yeasts. Trends Food Sci. Technol. 1998, 9, 267-274. [CrossRef]

10. De Vuyst, L.; Vrancken, G.; Ravyts, F.; Rimaux, T.; Weckx, S. Biodiversity, ecological determinants, and metabolic exploitation of sourdough microbiota. Food Microbiol. 2009, 26, 666-675. [CrossRef]

11. Corsetti, A.; De Angelis, M.; Dellaglio, F.; Paparella, A.; Fox, P.F.; Settanni, L.; Gobbetti, M. Characterization of sourdough lactic acid bacteria based on genotypic and cell-wall protein analyses. J. Appl. Microbiol. 2003, 94, 641-654. [CrossRef]

12. De Vuyst, L.; Van Kerrebroeck, S.; Harth, H.; Huys, G.; Daniel, H.-M.; Weckx, S. Microbial ecology of sourdough fermentations: diverse or uniform? Food Microbiol. 2014, 37, 11-29. [CrossRef]

13. Gullo, M.; Romano, A.D.; Pulvirenti, A.; Giudici, P. Candida humilis-dominant species in sourdoughs for the production of durum wheat bran flour bread. Int. J. Food Microbiol. 2003, 80, 55-59. [CrossRef]

14. Succi, M.; Reale, A.; Andrighetto, C.; Lombardi, A.; Sorrentino, E.; Coppola, R. Presence of yeasts in southern Italian sourdoughs from Triticum aestivum flour. FEMS Microbiol. Lett. 2003, 225, 143-148. [CrossRef]

15. Gobbetti, M.; Corsetti, A.; Rossi, J. The sourdough microflora. Interactions between lactic acid bacteria and yeasts: metabolism of amino acids. World J. Microbiol. Biotechnol. 1994, 10, 275-279. [CrossRef] [PubMed]

16. Rizzello, C.G.; Calasso, M.; Campanella, D.; De Angelis, M.; Gobbetti, M. Use of sourdough fermentation and mixture of wheat, chickpea, lentil and bean flours for enhancing the nutritional, texture and sensory characteristics of white bread. Int. J. Food Microbiol. 2014, 180, 78-87. [CrossRef] [PubMed]

17. Hammes, W.P.; Brandt, M.J.; Francis, K.L.; Rosenheim, J.; Seitter, M.F.H.; Vogelmann, S.A. Microbial ecology of cereal fermentations. Trends Food Sci. Technol. 2005, 16, 4-11. [CrossRef]

18. Komlenić, D.K.; Ugarčić-Hardi, Ž.; Jukić, M.; Planinić, M.; Bucić-Kojić, A.; Strelec, I. Wheat dough rheology and bread quality effected by Lactobacillus brevis preferment, dry sourdough and lactic acid addition. Int. J. Food Sci. Technol. 2010, 45, 1417-1425. [CrossRef]

19. Meroth, C.B.; Hammes, W.P.; Hertel, C. Characterisation of the microbiota of rice sourdoughs and description of Lactobacillus spicheri sp. nov. Syst. Appl. Microbiol. 2004, 27, 151-159. [CrossRef]

20. Vancanneyt, M.; Neysens, P.; De Wachter, M.; Engelbeen, K.; Snauwaert, C.; Cleenwerck, I.; Van der Meulen, R.; Hoste, B.; Tsakalidou, E.; De Vuyst, L.; et al. Lactobacillus acidifarinae sp. nov. and Lactobacillus zymae sp. nov., from wheat sourdoughs. Int. J. Syst. Evol. Microbiol. 2005, 55, 615-620. [CrossRef] 
21. Arendt, E.K.; Ryan, L.A.M.; Dal Bello, F. Impact of sourdough on the texture of bread. Food Microbiol. 2007, 24, 165-174. [CrossRef]

22. Sadeghi, A.; Ebrahimi, M.; Mortazavi, S.A.; Abedfar, A. Application of the selected antifungal LAB isolate as a protective starter culture in pan whole-wheat sourdough bread. Food Control 2019, 95, 298-307. [CrossRef]

23. Corsetti, A.; Gobbetti, M.; Rossi, J.; Damiani, P. Antimould activity of sourdough lactic acid bacteria: Identification of a mixture of organic acids produced by Lactobacillus sanfrancisco CB1. Appl. Microbiol. Biotechnol. 1998, 50, 253-256. [CrossRef] [PubMed]

24. Benozzi, E.; Romano, A.; Capozzi, V.; Makhoul, S.; Cappellin, L.; Khomenko, I.; Aprea, E.; Scampicchio, M.; Spano, G.; Märk, T.D.; et al. Monitoring of lactic fermentation driven by different starter cultures via direct injection mass spectrometric analysis of flavour-related volatile compounds. Food Res. Int. 2015, 76, 682-688. [CrossRef] [PubMed]

25. Kline, L.; Sugihara, T.F. Microorganisms of the San Francisco sour dough bread process. II. Isolation and characterization of undescribed bacterial species responsible for the souring activity. Appl. Microbiol. 1971, 21, 459-465. [CrossRef] [PubMed]

26. Neubauer, H.; Glaasker, E.; Hammes, W.P.; Poolman, B.; Konings, W.N. Mechanism of maltose uptake and glucose excretion in Lactobacillus sanfrancisco. J. Bacteriol. 1994, 176, 3007-3012. [CrossRef]

27. Gobbetti, M.; Corsetti, A.; Rossi, J. The sourdough microflora. Interactions between lactic acid bacteria and yeasts: metabolism of carbohydrates. Appl. Microbiol. Biotechnol. 1994, 41, 456-460. [CrossRef]

28. Gobbetti, M.; Simonetti, M.S.; Rossi, J.; Cossignani, L.; Corsetti, A.; Damiani, P. Free D- and L-Amino Acid Evolution During Sourdough Fermentation and Baking. J. Food Sci. 1994, 59, 881-884. [CrossRef]

29. Sieuwerts, S.; Bron, P.A.; Smid, E.J. Mutually stimulating interactions between lactic acid bacteria and Saccharomyces cerevisiae in sourdough fermentation. LWT 2018, 90, 201-206. [CrossRef]

30. Mendes, F.; Sieuwerts, S.; de Hulster, E.; Almering, M.J.H.; Luttik, M.A.H.; Pronk, J.T.; Smid, E.J.; Bron, P.A.; Daran-Lapujade, P. Transcriptome-based characterization of interactions between Saccharomyces cerevisiae and Lactobacillus delbrueckii subsp. bulgaricus in lactose-grown chemostat cocultures. Appl. Environ. Microbiol. 2013, 79, 5949-5961. [CrossRef]

31. Cheirsilp, B.; Shoji, H.; Shimizu, H.; Shioya, S. Interactions between Lactobacillus kefiranofaciens and Saccharomyces cerevisiae in mixed culture for kefiran production. J. Biosci. Bioeng. 2003, 96, 279-284. [CrossRef]

32. Sieuwerts, S.; de Bok, F.A.M.; Hugenholtz, J.; van Hylckama Vlieg, J.E.T. Unraveling microbial interactions in food fermentations: from classical to genomics approaches. Appl. Environ. Microbiol. 2008, 74, 4997-5007. [CrossRef]

33. Smid, E.J.; Lacroix, C. Microbe-microbe interactions in mixed culture food fermentations. Curr. Opin. Biotechnol. 2013, 24, 148-154. [CrossRef] [PubMed]

34. Alexandre, H.; Costello, P.J.; Remize, F.; Guzzo, J.; Guilloux-Benatier, M. Saccharomyces cerevisiae-Oenococcus oeni interactions in wine: current knowledge and perspectives. Int. J. Food Microbiol. 2004, 93, 141-154. [CrossRef] [PubMed]

35. Sieuwerts, S.; Molenaar, D.; van Hijum, S.A.F.T.; Beerthuyzen, M.; Stevens, M.J.A.; Janssen, P.W.M.; Ingham, C.J.; de Bok, F.A.M.; de Vos, W.M.; van Hylckama Vlieg, J.E.T. Mixed-culture transcriptome analysis reveals the molecular basis of mixed-culture growth in Streptococcus thermophilus and Lactobacillus bulgaricus. Appl. Environ. Microbiol. 2010, 76, 7775-7784. [CrossRef]

36. Viljoen, B.C. The interaction between yeasts and bacteria in dairy environments. Int. J. Food Microbiol. 2001, 69, 37-44. [CrossRef]

37. Berbegal, C.; Garofalo, C.; Russo, P.; Pati, S.; Capozzi, V.; Spano, G. Use of Autochthonous Yeasts and Bacteria in Order to Control Brettanomyces bruxellensis in Wine. Fermentation 2017, 3, 65. [CrossRef]

38. Russo, P.; Fares, C.; Longo, A.; Spano, G.; Capozzi, V. Lactobacillus plantarum with Broad Antifungal Activity as a Protective Starter Culture for Bread Production. Foods 2017, 6, 110. [CrossRef] [PubMed]

39. Capozzi, V.; Russo, P.; Fragasso, M.; De Vita, P.; Fiocco, D.; Spano, G. Biotechnology and pasta-making: Lactic Acid bacteria as a new driver of innovation. Front. Microbiol. 2012, 3, 94. [CrossRef]

40. Goesaert, H.; Brijs, K.; Veraverbeke, W.S.; Courtin, C.M.; Gebruers, K.; Delcour, J.A. Wheat flour constituents: How they impact bread quality, and how to impact their functionality. Trends Food Sci. Technol. 2005, 16, 12-30. [CrossRef]

41. Moore, M.M.; Juga, B.; Schober, T.J.; Arendt, E.K. Effect of Lactic Acid Bacteria on Properties of Gluten-Free Sourdoughs, Batters, and Quality and Ultrastructure of Gluten-Free Bread. Cereal Chem. 2007, 84, 357-364. [CrossRef] 
42. Coda, R.; Rizzello, C.G.; Gobbetti, M. Use of sourdough fermentation and pseudo-cereals and leguminous flours for the making of a functional bread enriched of $\gamma$-aminobutyric acid (GABA). Int. J. Food Microbiol. 2010, 137, 236-245. [CrossRef]

43. Corsetti, A.; Settanni, L. Lactobacilli in sourdough fermentation. Food Res. Int. 2007, 40, 539-558. [CrossRef]

44. Chavan, R.S.; Chavan, S.R. Sourdough Technology-A Traditional Way for Wholesome Foods: A Review. Compr. Rev. Food Sci. Food Saf. 2011, 10, 169-182. [CrossRef]

45. Vinderola, G.; Ouwehand, A.; Salminen, S.; von Wright, A. Lactic Acid Bacteria: Microbiological and Functional Aspects; CRC Press: Boca Raton, FL, USA, 2019; ISBN 978-0-429-61564-1.

46. Blandino, A.; Al-Aseeri, M.E.; Pandiella, S.S.; Cantero, D.; Webb, C. Cereal-based fermented foods and beverages. Food Res. Int. 2003, 36, 527-543. [CrossRef]

47. Rodrigues, F.; Ludovico, P.; Leão, C. Sugar Metabolism in Yeasts: An Overview of Aerobic and Anaerobic Glucose Catabolism. In Biodiversity and Ecophysiology of Yeasts; Péter, G., Rosa, C., Eds.; The Yeast Handbook; Springer: Berlin/Heidelberg, Germany, 2006; pp. 101-121, ISBN 978-3-540-30985-7.

48. Korakli, M.; Rossmann, A.; Gänzle, M.G.; Vogel, R.F. Sucrose metabolism and exopolysaccharide production in wheat and rye sourdoughs by Lactobacillus sanfranciscensis. J. Agric. Food Chem. 2001, 49, 5194-5200. [CrossRef]

49. Gänzle, M.G.; Loponen, J.; Gobbetti, M. Proteolysis in sourdough fermentations: mechanisms and potential for improved bread quality. Trends Food Sci. Technol. 2008, 19, 513-521. [CrossRef]

50. Tuukkanen, K.; Loponen, J.; Mikola, M.; Sontag-Strohm, T.; Salovaara, H. Degradation of secalins during rye sourdough fermentation. Cereal Chem. 2005, 82, 677-682. [CrossRef]

51. Di Cagno, R.; De Angelis, M.; Auricchio, S.; Greco, L.; Clarke, C.; De Vincenzi, M.; Giovannini, C.; D'Archivio, M.; Landolfo, F.; Parrilli, G.; et al. Sourdough bread made from wheat and nontoxic flours and started with selected lactobacilli is tolerated in celiac sprue patients. Appl. Environ. Microbiol. 2004, 70, 1088-1096. [CrossRef]

52. Wieser, H.; Vermeulen, N.; Gaertner, F.; Vogel, R.F. Effects of different Lactobacillus and Enterococcus strains and chemical acidification regarding degradation of gluten proteins during sourdough fermentation. Eur. Food Res. Technol. 2008, 226, 1495-1502. [CrossRef]

53. Gänzle, M.G.; Vermeulen, N.; Vogel, R.F. Carbohydrate, peptide and lipid metabolism of lactic acid bacteria in sourdough. Food Microbiol. 2007, 24, 128-138. [CrossRef]

54. Christensen, J.E.; Dudley, E.G.; Pederson, J.A.; Steele, J.L. Peptidases and amino acid catabolism in lactic acid bacteria. Antonie Van Leeuwenhoek 1999, 76, 217-246. [CrossRef]

55. Gobbetti, M.; Smacchi, E.; Corsetti, A. The proteolytic system of Lactobacillus sanfrancisco CB1: purification and characterization of a proteinase, a dipeptidase, and an aminopeptidase. Appl. Environ. Microbiol. 1996, 62, 3220-3226. [CrossRef] [PubMed]

56. Di Cagno, R.; De Angelis, M.; Lavermicocca, P.; De Vincenzi, M.; Giovannini, C.; Faccia, M.; Gobbetti, M. Proteolysis by sourdough lactic acid bacteria: effects on wheat flour protein fractions and gliadin peptides involved in human cereal intolerance. Appl. Environ. Microbiol. 2002, 68, 623-633. [CrossRef] [PubMed]

57. De Angelis, M.; Gallo, G.; Corbo, M.R.; McSweeney, P.L.H.; Faccia, M.; Giovine, M.; Gobbetti, M. Phytase activity in sourdough lactic acid bacteria: purification and characterization of a phytase from Lactobacillus sanfranciscensis CB1. Int. J. Food Microbiol. 2003, 87, 259-270. [CrossRef]

58. Lopez, H.W.; Krespine, V.; Guy, C.; Messager, A.; Demigne, C.; Remesy, C. Prolonged fermentation of whole wheat sourdough reduces phytate level and increases soluble magnesium. J. Agric. Food Chem. 2001, 49, 2657-2662. [CrossRef] [PubMed]

59. Hansen, A.; Schieberle, P. Generation of aroma compounds during sourdough fermentation: applied and fundamental aspects. Trends Food Sci. Technol. 2005, 16, 85-94. [CrossRef]

60. Giannou, V.; Kessoglou, V.; Tzia, C. Quality and safety characteristics of bread made from frozen dough. Trends Food Sci. Technol. 2003, 14, 99-108. [CrossRef]

61. Pico, J.; Khomenko, I.; Capozzi, V.; Navarini, L.; Bernal, J.; Gómez, M.; Biasioli, F. Analysis of volatile organic compounds in crumb and crust of different baked and toasted gluten-free breads by direct PTR-ToF-MS and fast-GC-PTR-ToF-MS. J. Mass Spectrom. JMS 2018, 53, 893-902. [CrossRef]

62. Capozzi, V.; Makhoul, S.; Aprea, E.; Romano, A.; Cappellin, L.; Sanchez Jimena, A.; Spano, G.; Gasperi, F.; Scampicchio, M.; Biasioli, F. PTR-MS Characterization of VOCs Associated with Commercial Aromatic Bakery Yeasts of Wine and Beer Origin. Molecules 2016, 21, 483. [CrossRef] 
63. Makhoul, S.; Romano, A.; Cappellin, L.; Spano, G.; Capozzi, V.; Benozzi, E.; Märk, T.D.; Aprea, E.; Gasperi, F.; El-Nakat, H.; et al. Proton-transfer-reaction mass spectrometry for the study of the production of volatile compounds by bakery yeast starters. J. Mass Spectrom. JMS 2014, 49, 850-859. [CrossRef]

64. Makhoul, S.; Romano, A.; Capozzi, V.; Spano, G.; Aprea, E.; Cappellin, L.; Benozzi, E.; Scampicchio, M.; Märk, T.D.; Gasperi, F.; et al. Volatile Compound Production During the Bread-Making Process: Effect of Flour, Yeast and Their Interaction. Food Bioprocess Technol. 2015, 8, 1925-1937. [CrossRef]

65. Tieking, M.; Ehrmann, M.A.; Vogel, R.F.; Gänzle, M.G. Molecular and functional characterization of a levansucrase from the sourdough isolate Lactobacillus sanfranciscensis TMW 1.392. Appl. Microbiol. Biotechnol. 2005, 66, 655-663. [CrossRef] [PubMed]

66. Sandra, G.; Schwab, C.; Bello, F.D.; Coffey, A.; Gänzle, M.; Arendt, E. Comparison of the impact of dextran and reuteran on the quality of wheat sourdough bread. J. Cereal Sci. 2012, 56, 531-537. [CrossRef]

67. Caggianiello, G.; Kleerebezem, M.; Spano, G. Exopolysaccharides produced by lactic acid bacteria: From health-promoting benefits to stress tolerance mechanisms. Appl. Microbiol. Biotechnol. 2016, 100, 3877-3886. [CrossRef] [PubMed]

68. Liukkonen, K.-H.; Katina, K.; Wilhelmsson, A.; Myllymäki, O.; Lampi, A.-M.; Kariluoto, S.; Piironen, V.; Heinonen, S.-M.; Nurmi, T.; Adlercreutz, H.; et al. Process-induced changes on bioactive compounds in whole grain rye. Proc. Nutr. Soc. 2003, 62, 117-122. [CrossRef]

69. Kariluoto, S.; Vahteristo, L.; Salovaara, H.; Katina, K.; Liukkonen, K.-H.; Piironen, V. Effect of Baking Method and Fermentation on Folate Content of Rye and Wheat Breads. Cereal Chem. 2004, 81, 134-139. [CrossRef]

70. Batifoulier, F.; Verny, M.-A.; Chanliaud, E.; Rémésy, C.; Demigné, C. Effect of different breadmaking methods on thiamine, riboflavin and pyridoxine contents of wheat bread. J. Cereal Sci. 2005, 42, 101-108. [CrossRef]

71. Russo, P.; Arena, M.P.; Fiocco, D.; Capozzi, V.; Drider, D.; Spano, G. Lactobacillus plantarum with broad antifungal activity: A promising approach to increase safety and shelf-life of cereal-based products. Int. J. Food Microbiol. 2017, 247, 48-54. [CrossRef]

72. Corona, O.; Alfonzo, A.; Ventimiglia, G.; Nasca, A.; Francesca, N.; Martorana, A.; Moschetti, G.; Settanni, L. Industrial application of selected lactic acid bacteria isolated from local semolinas for typical sourdough bread production. Food Microbiol. 2016, 59, 43-56. [CrossRef]

73. Larsson, M.; Sandberg, A.-S. Phytate reduction in bread containing oat flour, oat bran or rye bran. J. Cereal Sci. 1991, 14, 141-149. [CrossRef]

74. Axel, C.; Zannini, E.; Arendt, E.K. Mold spoilage of bread and its biopreservation: A review of current strategies for bread shelf life extension. Crit. Rev. Food Sci. Nutr. 2017, 57, 3528-3542. [CrossRef]

75. Messens, W.; De Vuyst, L. Inhibitory substances produced by Lactobacilli isolated from sourdoughs-a review. Int. J. Food Microbiol. 2002, 72, 31-43. [CrossRef]

76. Lavermicocca, P.; Valerio, F.; Evidente, A.; Lazzaroni, S.; Corsetti, A.; Gobbetti, M. Purification and characterization of novel antifungal compounds from the sourdough Lactobacillus plantarum strain $21 \mathrm{~B}$. Appl. Environ. Microbiol. 2000, 66, 4084-4090. [CrossRef] [PubMed]

77. Larsen, A.G.; Vogensen, F.K.; Josephsen, J. Antimicrobial activity of lactic acid bacteria isolated from sour doughs: purification and characterization of bavaricin A, a bacteriocin produced by Lactobacillus bavaricus MI401. J. Appl. Bacteriol. 1993, 75, 113-122. [CrossRef] [PubMed]

78. Gänzle, M.G.; Höltzel, A.; Walter, J.; Jung, G.; Hammes, W.P. Characterization of reutericyclin produced by Lactobacillus reuteri LTH2584. Appl. Environ. Microbiol. 2000, 66, 4325-4333. [CrossRef]

79. Ryan, L.A.; Dal Bello, F.; Arendt, E.K. The use of sourdough fermented by antifungal LAB to reduce the amount of calcium propionate in bread. Int. J. Food Microbiol. 2008, 125, 274-278. [CrossRef]

80. Garofalo, C.; Zannini, E.; Aquilanti, L.; Silvestri, G.; Fierro, O.; Picariello, G.; Clementi, F. Selection of sourdough lactobacilli with antifungal activity for use as biopreservatives in bakery products. J. Agric. Food Chem. 2012, 60, 7719-7728. [CrossRef]

81. Cizeikiene, D.; Juodeikiene, G.; Paskevicius, A.; Bartkiene, E. Antimicrobial activity of lactic acid bacteria against pathogenic and spoilage microorganism isolated from food and their control in wheat bread. Food Control 2013, 31, 539-545. [CrossRef]

(C) 2020 by the authors. Licensee MDPI, Basel, Switzerland. This article is an open access article distributed under the terms and conditions of the Creative Commons Attribution (CC BY) license (http://creativecommons.org/licenses/by/4.0/). 